\title{
GEOGRAFIAS DO AFETO E DO DESTERRO
}

Analice de Oliveira Martins ${ }^{1}$

ORCID: https://orcid.org/0000-0003-1136-9527

Deriva (2019) é o terceiro livro de poemas de Adriana Lisboa, escritora que se desloca sem sobressaltos entre a prosa e a poesia, a literatura e a música, o vivido e o imaginado. Agraciada em 2003 com o prêmio José Saramago por Sinfonia em branco (2001), a autora, também mulher em trânsito entre cidades e países, colhe dessas percepções a matéria porosa de sua poética, como afirma em entrevista a Luciano Trigo²:

Ser imigrante é uma experiência bem vinda, porque isso me tira da zona de conforto e sublinha coisas que eu de hábito não notaria, tanto no lugar onde moro quanto no lugar de onde venho, já que mudei o ângulo de observação, mas também convivo com uma sensação muito grande de deslocamento no mundo [...] Gosto de ser imigrante (claro, sou vista como imigrante, sempre), gosto das diferenças.

Em quase todas as acepções da palavra "deriva", persiste a ideia de movimento, seja na atitude de desviar-se, mudar de rumos, seja na de originar-se, proceder ou provir. No livro em questão, ir e vir, chegar e partir não se excluem; complementam-se mais do que se apartam, como afirma a voz lírica em "O que fica para trás”: “e que partir sempre/ é outra maneira/ de ficar". (LISBOA, 2019, p.51). Ou se interroga em "West End Blues": "por que falhas partir/ por que frestas/ ficar" (LISBOA, 2019, p.30).

\footnotetext{
${ }^{1}$ Doutora em Estudos de Literatura pela PUC-Rio. Professora titular do Instituto Federal Fluminense (IFF) e professora colaboradora do Programa de Mestrado e Doutorado em Cognição e Linguagem da Universidade Estadual do Norte Fluminense Darcy Ribeiro (UENF). Autora de vários artigos acadêmicos e do livro Entremeios: ensaios sobre literatura, cinema e comunicação (2018).

${ }^{2}$ Entrevista concedida ao escritor e jornalista Luciano Trigo, quando do lançamento do romance Hanói, em 2013. Disponível em: http://g1.globo.com/platb/maquinadeescrever/2013/06/02/1522/. Último acesso em $14 / 05 / 2020$.
} 
A temática do estrangeiro, do sujeito em movimento entre culturas e línguas, está também presente em seus romances, Rakushsiha (2007), Azul corvo (2010) e Hanói (2013). Mas, se neles há personagens nomeados, em Deriva, a voz lírica só delineia perfis vez ou outra em algumas referências literárias, musicais ou espaciais. Trata-se também de um mundo em dissolução: “- abençoada esta/ falência este desfalque/esta dissolução” (LISBOA, 2019, p. 26).

A autora elege, portanto, um ponto de vista que tira proveito ou mesmo se encanta diante do desassossego da estrangeiridade, num jogo entre pertencer e estar à margem, morar e estar de passagem. É desse lugar de enunciação que observa, em "Esfumaçar bordas", os centros se destruírem, as matrizes incendiarem. Como preconiza o filósofo Michel Maffesoli (2001, p.95), em Sobre o nomadismo: vagabundagens pós-modernas, "Ninguém pode se gabar de ter uma morada permanente. Em suas diversas manifestações, a vida é sempre um caminhar entre o aqui e o alhures". Da mesma forma, os sujeitos em deriva estão sempre por um tempo a "habitar um não-tempo" (LISBOA, 2019, p.29), na transitoriedade do contingente que anuncia uma cartografia outra, como em "Desmapa”: “(o que ainda há a mapear?/ e que interesse há convenhamos/ em saber que chão é este?)” (LISBOA, 2019, p.29).

Há, em Deriva, três situações bem delineadas e também entrelaçadas de deslocamento ou de trânsito: a social, a lírico-amorosa e a artística. Quanto ao aspecto social, a condição estrangeira, migrante, à margem da sociedade, constitui uma voz enunciativa recorrente em vários poemas, transcendendo o aspecto intimista e olhando ao redor, ao redor do mundo. Em "Meu amigo", afigura-se o enfrentamento diário daquele que se sente "ilhado, endividado, acossado", mas ainda assim sai à rua e faz o mundo se dobrar "aos dentes explícitos que ele arrisca/ por baixo do veludo do batom” (LISBOA, 2019, p.16). Tempos calcários de "descumprir as ordens do patrão" e arrancar "da terra mais preta [...] a insurreição de um pé de fruta" (LISBOA, 2019, p. 18). Por isso, o estar à margem faz parecer que "viver é estar/ quase sempre na fila errada" (LISBOA, 2019, p.31)

De forma ainda mais explícita, no poema "Migrantes", abre-se a ferida contemporânea dos trânsitos compulsórios, do "cosmopolitismo do pobre", na expressão do crítico literário Silviano Santiago (2004), situação na qual a identidade que se carrega na mala não é um documento, mas sim o idioma nacional, a casa abandonada, numa viagem errática e de subtração: “mas agora desancorados já não sabem/ em idioma algum o que 
deixam/ nem o que são/ nem o que somam/ nesta viagem que é um longo/ e lento aprender a flexionar/ sinais de subtração" (LISBOA, 2019, p.53).

A reflexão sobre a morada do Outro que se passa a habitar realoca antigos pertencimentos e subverte as raízes. Se as matrizes se incendiaram, o subterrâneo da raiz há de ser improvisado com outros recursos, extraído do ar, pois, na pátria dos outros, deve-se “calcar os pés[...] errar/ a fala dos outros calar/ a língua dos outros" (LISBOA, 2019, p.52).

Os migrantes contemporâneos partem desancorados, queimam navios, não como o fizeram os gregos antigos (para vencer ou morrer), como adverte a voz lírica, mas porque ardem sós: "queimar navios [...] como/ quem finca os pés/ na proa de um novo mundo/ e arde por si/ só", divisando "linha de vida tão frágil", "âncora unhada no chão" (LISBOA, 2019, p. 57), para, então, como vislumbra a voz lírica no poema "Deriva”, "tocar com o dedo/ uma linha de chegada/ um porto entre duas clavículas/ tanta morte iludida/ pela ilusão de uma praia/ por um avesso de oásis/ na enormidade deste mar sertão" (LISBOA, 2019, p. 59).

Em “A um amigo que espera", a voz lírica diz encontrar-se "empoleirada num mundo que tende à ruina" (LISBOA, 2019, p. 64), à dissolução e ao desfalque. É tal condição que coloca em trânsito, in motion (em movimento) toda sorte de estrangeiros (trabalhadores, exilados, refugiados, ilhados). O eu que se vê esfumaçado em "Espelho meu" é o mesmo que sai “à praça contra o intolerável” (LISBOA, 2019, p.65). Do mais íntimo e privado ao mais público, há sempre um movimento de pertencimento ou de desenraizamento.

Do ponto de vista lírico-amoroso, geografias e afetos se abraçam, por vezes, acalentando o desterro, como em "Alpine, Texas":

\author{
Meu corpo e o seu \\ à deriva \\ no sono num quarto de hotel \\ em dois cantos da cama \\ por demais king size, \\ [...] mas basta esticar o braço \\ basta esticar o braço e \\ alcançar o seu corpo este \\ que há mais de uma década \\ encontro \\ no fundo da noite \\ que habitamos \\ em qualquer Alpine, Texas \\ em qualquer lugar". (LISBOA, 2019, p.22)
}


Para o desamparo do desterro, resta, ainda que tímido, "o refúgio deste mundo/ o arrimo desse amor" (LISBOA, 2019, p.23), mas que também não é porto seguro, como alerta, com alguma acidez, a voz lírica: "Eu te darei o céu meu bem/ (o paraquedas/ é por sua conta)" (LISBOA, 2019, p. 43).

Esses versos últimos fazem parte de uma seção intitulada "Três canções", em que letras de música são o mote para os poemas, não apenas em exercício intertextual, como também no trânsito entre palavra e melodia, palavra e memória musical, espécie de deriva autoficcional da Adriana musicista: "Roçar o arco sutilmente/ sobre as cordas da viola roçar/ o mínimo roçar/ o suficiente/ para produzir um som [...] este som sem adjetivos este som/ que existe em meus ouvidos" (LISBOA, 2019, p. 36). Mas talvez seja na memória afetiva que as melodias se tornem mais densas e penetrantes: "minha mãe a me tomar nos braços/ a dançar comigo/ ao ritmo do jazz-band" (LISBOA, 2019, p.46) ou no "chiado da palha da vassoura" do velho varrendo a calçada em Havana (LISBOA, 2019, p.49).

Quando a voz lírica se pergunta o que há ainda a mapear, talvez, seja possível pensar também nos territórios da palavra, pois não restam dúvidas de que Deriva propõe que se habitem "uns versos/ a que não falte um estranho/ - o grão de sal e mostarda/ um grau de atrito detrito/ dissenso [...] umas palavras válidas por hoje" (LISBOA, 2019, p.19). A partir das percepções do "estranho" e do "dissenso", Adriana Lisboa traduz em versos, portanto, as derivas do contemporâneo.

\section{Referências}

LISBOA, A. Rakushisha. Rio de Janeiro: Rocco, 2007.

LISBOA, A. Azul Corvo. Rio de Janeiro: Rocco, 2010.

LISBOA, A. Hanói. Rio de Janeiro, Alfaguarra, 2013.

LISBOA, A. Deriva. Belo Horizonte: Relicário, 2019.

MAFFESOLI, M. Sobre o nomadismo: vagabundagens pós-modernas. Rio de Janeiro: Record, 2001.

SANTIAGO, S. O cosmopolitismo do pobre: crítica literária e crítica cultural. Belo Horizonte: UFMG, 2004. 
A. O. Martins

Geografias do afeto e do desterro

Resenha recebida em: 15.03. 2021

Resenha aceita para publicar em: 07.07.2021 